УДК 811.111'37’42

DOI https://doi.org/10.26661/2414-9594-2020-2-7

\title{
ЕКСТРАЛІНГВАЛЬНІ ТА МОВНІ ОСОБЛИВОСТІ НЕОЛОГІЗМІВ ЛЕКСИКО-СЕМАНТИЧНОГО ПОЛЯ «КОРОНАВІРУС»
}

\author{
Гонта I. A. \\ кандидат філологічних наук, доиент, \\ дочент кафедри іноземних мов хіміко-фізичних факультетів \\ Київський національний університет імені Тараса Шевченка \\ вул. Володимирська, 64/13, Київ, Україна \\ orcid.org/0000-0002-8784-4059 \\ ihonta@ukr.net
}

\begin{abstract}
Ключові слова: лексикосемантична підгрупа, композитний словотвір, контамінація, ітеративний та інтегральний компоненти, метафоричне та асоціативне значення.
\end{abstract}

Сьогодні лінгвістичної актуальності набуває комплексне дослідження конкретних екстралінгвальних (культурних, соціальних, економічних) умов та лінгвістичних (структурних, семантичних та словотвірних) особливостей утворення нових лексичних та фразеологічних одиниць, що виникли у час глобальної пандемії коронавірусу, вперше виявленої в Китаї та згодом поширеної в усьому світі. Інтенсивним періодом словотвору став період жорсткого карантину, що тривав 3 березня по червень 2020 року.

Особливий інтерес викликають новоутворення 3 ітеративними компонентами corona, quarantine. Зручним способом їх семантичної класификації $є$ структурування в лексико-семантичні поля, як парадигмальні об'єднання лексичних одиниць за спільністю інтегрального компонента значення або ж архісеми. Таке структурування дозволяє виділити суттєво більшу кількість лексико-семантичних підгруп. У статті досліджується лексико-семантичне поле «Коронавірус» 3 ітеративними інтегральними компонентами corona та quarantine. Мотивацією аналізу лексико-семантичних поля «корона вірус» із цими компонентами є велика кількість мовних одиниць, утворених за участю саме цих ітеративних інтегральних компонентів. Лексико-семантичними підгрупами новоутворень у межах цього лексико-семантичного поля $\epsilon$ лексико-семантичні підгрупи на позначення самої людини та іiі характеристик, iï характерної зовнішності, поведінки, соціальноекономічних змін (зокрема в економічній діяльності людини), змін, пов'язаних із міжособистими стосунками, змін, пов'язаних із навчанням та дозвіллям.

Аналіз структурних, семантичних та словотвірних характеристик таких новоутворень дозволив визначити композитний спосіб словотвору, контамінацію, усічення компонентів слів як особливо продуктивні види структурного словотвору, метафоризацію - як продуктивний спосіб їх семантичного словотвору. Інтегральні ітеративні компоненти corona, quarantine в більшості новоутворень $є$ ономасіологічною ознакою цих новоутворень, тоді як інший компонент у складі композити або словосполучення виступає ономасіологічним базисом.

Мовні новоутворення характеризуються розширеною роллю конотативного компонента в їх семантиці, причинами чого є їх новизна та актуальність, структурні характеристики (композити та контамінанти), яскраве метафоричне та асоціативне значення. 


\title{
EXTRALINGUISTIC AND LINGUISTIC PECULARITIES OF NEOLOGISMS OF LEXICO-SEMANTIC FIELD 'CORONA VIRUS'
}

\author{
Honta I. A. \\ Candidate of Philological Sciences, Associate Professor, \\ Associate Professor at the Department of Foreign Languages \\ for Chemistry and Physics Faculties \\ Taras Shevchenko National University of Kyiv \\ Volodymyrska str., 64/13, Kyiv, Ukraine \\ orcid.org/0000-0002-8784-4059 \\ ihonta@ukr.net
}

Key words: lexico-semantic subgroup, compounding, blending, iterative and integrative component, metaphorical and associative meaning.

\begin{abstract}
Currently in the conditions of global corona virus pandemic, which began at the beginning of 2020 in China and quickly spread all around the world, the complex investigation of precise extralinguistic conditions and linguistic (structural, semantic and derivative) pecularities for creating new lexical and phraseological units is becoming increasingly actual in Linguistics. The period of quarantine which lasted from March to June 2020 was especially intensive in the coinage of neologisms.

New language units with iterative components corona and quarantine are of special interest. A convenient way of their classification is their structuring into lexico-semantic fields, which are paradigmatic integration of language units according to the integral component of their meaning or archiseme. This structuring allows singularizing an essentially greater number of lexico-semantic subgroups. The article deals with the lexico-semantic field 'Coronavirus' with iterative and integrative components corona and quarantine. The complex linguistic analysis of the the lexico-semantic field 'Coronavirus' is motivated by an increasing quantity of new language units created by means of the above-mentioned components. Lexico-semantic subgroups of these new language units are those denoting a human and his/her characteristics, his/her appearance, behavior, social and economic changes (in particular, changes in the economic activity of people), changes related to interpersonal relationships, changes related to education and entertainment.

The analysis of structural, semantic and word-building features of these language units resulted in determining compounding, blending, abridging components as particularly productive means of the structural coinage of new language units and metaphorization - as a productive means of semantic derivation. The integral iterative components corona and quarantine are an onomaseological feature of the newly created language units, while the other component within a compound or a blended word is their onomaseological basis.

The new language units are characterized by an expanded role of the connotation component in their semantics, the reasons of which are their novelty and urgency, structural features (compound and blended structure), bright metaphorical and associative meaning.
\end{abstract}

Постановка проблеми. В умовах пандемії коронавірусу актуальності набуває комплексне дослідження неологізмів, що виникають та поширюються, збагачуючи вокабуляр сучасної англійської мови. Комплексне дослідження цих неологізмів визначає актуальність дослідження. Особливий інтерес становлять численні мовні одиниці, які містять у собі такі лексико-семантичні компоненти, як corona, quarantine. Екстралінгвістичні чинники їх формування, структурно-семантичні та словотвірні особливості становлять предмет дослідження. Матеріалом дослідження стали 48 неологізмів, вибраних з онлайн словників [1-3]. 
Метою статті $\epsilon$ висвітлення характерних екстралінгвістичних (культурних, соціальних, економічних) умов утворення нових мовних одиниць 3 компонентами corona, quarantine, що виникли в умовах пандемії коронавірусу та аналіз їх загальних структурних, лексико-семантичних та словотвірних особливостей, а також спроба ïx класифікації та структурування в межах лексико-семантичного поля на лексико-семантичні підгрупи (ЛСПГ). Зауважимо, що мовні новоутворення, що виникли в умовах пандемії коронавірусу та повного або часткового карантину, ще не були об“єктом комплексних лінгвістичних досліджень, суміжним було дослідження коронавірусу як нового концепту в публіцистичних виданнях англійської мови [4], у якому поверхнево було згадано бленд як основний спосіб словотвору даних новоутворень, їх метафоричне та конотативне значення [4, с. 152]. У зазначеному дослідженні було розглянуто 18 мовних одиниць, вибраних 3 лексикографічних джерел.

Виклад основного матеріалу дослідження. Польове структурування мовних одиниць (зокрема лексичних) є продуктивним і надійним методом вивчення мовного складу мови. Лексико-семантичні поля характеризуються зв'язком слів або їх значень, системним характером цих зв'язків, що забезпечує безперервність смислового простору [5]. Лексико-семантичне поле визначаємо як парадигмальне об'єднання лексичних одиниць за спільністю інтегрального компонента значення або ж архісеми [6, с. 281], у ролі яких у нашому випадку виступають слова corona, quarantine. Лексико-семантичні підгрупи включають мовні одиниці з більш конкретним інтегральним компонентом значення.

Загалом соціально-економічні ситуація та наслідки коронавірусу відображається в лінгвістичному світі вже наявним лексичним та фразеологічним арсеналом, проте виникають чисельні неологізми для відображення пов'язаних із пандемією реалій, особливо складних реалій із метою економії мовних засобів та мовленнєвих зусиль. Швидке поширення вірусу призвело до появи нових реалій, що відобразилося в англійській мові в неологізмах, які можна об'єднати в лексико-семантичне поле (ЛСП) «Коронавірус», ітеративними компонентами якого є слова corona, quarantine. Це ЛСП включає більш конкретні лексико-семантичні підгрупи (ЛСПГ):

ЛСПГ «Період пандемії та карантину»: coronatimes - час та діяльність в період поширення пандемії; quarantimes - період перебування в умовах карантину під час корона вірусу.

ЛСПГ «Людина», мовні одиниці якої позначають власне людину з притаманними для неї характеристиками в умовах пандемії: лексема coronials виникла і була поширена в 3МІ внаслідок припущень та дискусій із приводу можливого зростання народжуваності в умовах, коли люди проводять набагато більше часу в умовах відносної ізоляції. Слово позначає гіпотетичну генерацію тих, хто має бути зачатий в цей період; quaranteens - покоління, що досягне підліткового віку в 2033-2034 роках; quaranqueens - жінки, що стають чудовими домогосподарками під час карантину; corona warriors - люди, що безпосередньо борються з пандемією; cuarantrolls - люди, що розсилають зловісні повідомлення, пов'язані з COVID-19; covidiot (також з ісп. covidiota) позначає тих, хто, нехтуючи правилами безпеки та умовами карантину, продовжує зустрічатися 3 друзями на вечірках і т.д. Подібним за значенням $\epsilon$ слово morona (morone+corona) на позначення людини 3 поведінкою, що нехтує правилами безпеки. Схожою, але більш конотативно-вульгарною $є$ лексема coronasshole, що спочатку позначала покупців, що масово скуповували товари, а потім ця лексема почала вживатись на позначення людей, що відмовлялись носити захисні маски; coronagrass - людина, яка доносить на порушників карантинних правил.

ЛСПГ «Поведінка людей» включає неологізми, які характеризують поведінку людей під час пандемії як в позитивному, так і в негативному аспектах: coronalusional позначає поведінку людини, що характеризується розладами, набутими під час періоду вимушеної ізоляції; coronacranky - роздратований або дратівливий, як наслідок постійного домашнього режиму; corona chivalry - благородна та самовіддана поведінка людей, що ризикують здоров'ям та життям в боротьбі з пандемією; coronasnitching - донос на людей, які порушують обмеження під час карантину; coronanoia - паранойя в умовах коронавірусу; coronaphobia - страх людейузв' язкузперспективоюповерненнядозвичних умов життєдіяльності; coronacoaster - сильні перепади підвищеного та пригніченого настрою, що відчуваються деякими людьми під час умов карантину. Очевидно лексема виникла за аналогією зі словом roller coaster - американські гірки; de-roning - намагання знищити всі сліди від коронавірусу після того, як людина прийшла додому; corona waltz - маневрування у громадських місцях із метою дотримання соціальної дистанції; coronadodge - теж саме; coronashaming - публічна критика відомих людей, що порушують карантинні правила та обмеження. Деякі люди намагаються використати вільний час для оновлення осель: ronavation (corona+renovation) - ремонт, перестановка, заміна меблів під час карантину.

ЛСПГ «Зовнішність людини»: coronacuts стрижка, зроблена непрофесійно в умовах карантину, особливо невдала; coronawear - одяг, який 
носять в умовах карантину; coronaspeck - надмірна вага, яку люди набувають в умовах карантину із причини малорухливого способу життя; corona-sheen - характерний відблиск на лобі та носі під час онлайн спілкування.

В умовах карантинних обмежень люди вимушені спілкуватись в онлайн-режимі, що відображається в мовних одиницях ЛСПГ «Онлай-спілкування»: quarandaiting - віртуальні побачення через прикладні програми мобільних телефонів в умовах карантину; corona-sheen - характерний відблиск на лобі та носі під час онлайн спілкування; coronaviva - усні іспити або захист студентської роботи в режимі онлайн.

Деякі неологізми складають ЛСПГ «Соціально-економічні зміни»: coronaverse - нові соціально-економічні умови та порядок під час пандемії; coronaclickbaiting - маркетингові стратегії компаній, що наживаються під час пандемії через інтернет-мережу; covexit - вихід із режиму карантину та обмежень та подолання економічних та соціальних наслідків епідемії; coronasplaining лексема 3 іронічним конотативним компонентом на позначення пояснення економічно-соціальних наслідків пандемії, особливо тим, хто є більш компетентним в цих питаннях; coronawashing діяльність корпорацій або людей, які використовують пандемію задля підвищення репутації, прикриваючись альтруїзмом; covidpreneurs - компанії та приватні підприємці, що процвітають в умовах пандемії; corona crunch - економічні наслідки від пандемії; coronaspiracy theries - теорії, думки та плітки про змову певних кіл, зацікавлених у поширенні коронавірусу та економічних наслідків, до яких призведе пандемія.

ЛСПГ «Навчання»: corona break - перерва в навчанні у зв'язку з пандемією, що вбачається деякими студентами та учнями, як вихідні. coronacation - перерва в навчанні або роботі у зв’язку з пандемією, що вбачається деякими студентами або працівниками, як канікули або відпустка; coronaviva - усні іспити або захист студентської роботи в режимі онлайн.

ЛСПГ «Дозвілля»: quaranstream - серіали та фільми, що переглядаються під час карантину; quarantunes - музика, що прослуховують під час карантину; coronalit - література, яка випускається під час карантину та пов'язана 3 тематикою карантину та пандеміі; quaranzine - журнал, що друкується або виходить під час карантину; corona- $f$ - фантастика, пов'язана 3 тематикою пандемії та коронавірусу; quaranttanning - засмагання з використанням спеціального устаткування в умовах карантинного режиму.

Ряд лексем можна об'єднати в ЛСПГ «Кулінарія»: Лексема quarantini (corona+martini) позначає напій, що складається із суміші мартіні, джина та порошку Emergen-C. Напій нібито готується для стимулювання імунітету. Лексема використовується також для позначення процесу вживання напою. Слово quaranbaking позначає явище, коли люди в умовах карантину витрачають більше часу на самостійне приготування страв, зокрема випічки.

Лексеми coronapocalypse (corona apocalypse) та coronageddon (corona armageddon) виникли як результат іронічного ставлення до гіпотетично-гіперболізованого кінця світу, що може статися внаслідок швидкого поширення вірусу і можуть бути об'єднані в ЛСПГ «Кінець світу».

Як бачимо, мовні одиниці лексико-семантичного поля «Коронавірус» характеризують людей за поведінкою, діяльністю, зовнішністю, ставленням до оточуючого світу, притаманними під час пандемії коронавірусу, номінуючи специфіку цієї поведінки в більш конкретних соціальних, економічних умовах. Спільність значення більшості цих мовних одиниць передається інтегральними ітеративними компонентами corona та quarantine в повній або скороченій формі, їх загальне значення конкретизується іншим компонентом (його повною або скороченою формою), який комбінується у складі композити, словосполучення. Ітеративні інтегральні компоненти corona та quarantine виступають ономасіологічними ознаками в межах ономасіологічного комплексу композит, тоді як інший компонент $\epsilon$, як правило, ономасіологічним базисом, тобто ядром значення.

Конотативне значення багатьох неологізмів посилюється метафоричним переносом. Особливо продуктивними способами словотвору $\epsilon$ словоскладання, контамінація, застосування яких $\epsilon$ широковживаними як в англійській [7-12], так і в українській мовах [13].

Характеризуючи дані мовні одиниці в семантичному плані, слід вказати на значну роль конотативного компонента їх значення в загальному складі лексичного значення, що пояснюється рядом лінгвістичних та екстралінгвістичних причин: 1) їхня новизна та актуальність; 2) їхня структура (серед них багато композитних слів, слів, утворених способом контамінації та абревіації); 3) асоціативне (як правило, метафоричне) значення.

Висновки. В умовах пандемії коронавірусу в англійській мові виникають мовні одиниці (як лексеми, так і стійкі словосполучення), в утворенні яких надзвичайно продуктивними є слова corona, quarantine. Неологізми в межах ЛСП «Коронавірус» можна згрупувати в такі лексикосемантичні підгрупи: «Час пандемії», «Людина», «Поведінка людини», «Навчання», «Міжособисті стосунки», «Онлайн-спілкування», «Дозвілля», «Соціально-економічна діяльність». Загальними 
словотвірними характеристиками цих новоутворень є широке використання композитного способу словотвору, контамінації, метафоричного переносу значення. Неологізми характеризуються розширеною роллю конотативного компонента, що пояснюється їхньою актуальністю, структурною архітектонікою та асоціативною (часто метафоричною) семантикою. Інтегральні ітера- тивні компоненти corona, quarantine в більшості новоутворень $є$ ономасіологічною ознакою цих новоутворень, тоді як інший компонент у складі композити або словосполучення виступають ономасіологічним базисом. Перспективами дослідження є подальший більш глибокий аналіз структурних, семантичних та словотвірних характеристик цих та інших неологізмів.

\section{ЛITEPATУРА}

1. Tony Thorne. Language and Innovation. Coronaspeak. The Language of Covid-19 Goes Viral. Part 2. URL: https:/language-and-innovation.com/2020/04/15/coronaspeak-part-2-the-language-of-covid-19goes-viral/.

2. New Words We Created Because of Coronavirus. URL: https://www.dictionary.com/e/s/new-words-wecreated-because-of-coronavirus/\#1.

3. Erin Mccarty. 11 New Words and Phrases Inspired by Coronavirus. URL: https://www.mentalfloss.com/ article/623726/new-words-inspired-coronavirus.

4. Красницька К. Глобальне явище Coronavirus як новий концепт в англомовній лінгвокогнітивній картині світу. Актуальні питання гуманітарних наук. 2020. Вип. 32, том 1. С. 148-151. URL: http://journals.uran.ua/index.php/2308-4855/article/view/214491.

5. Вабіщевич Н. Лексико-семантичне поле «вогню» в англійській мові. URL: https://naub.oa.edu.ua/ 2012/leksyko-semantychne-pole-vohnyu-v-anhlijskij-movi/.

6. Ярцева В.Н. Лингвистичечкий энциклопедический словарь / Гл. ред. В.Н. Ярцева. 2-е изд. дополненное. Москва : Большая Российская энциклопедия, 2002. 709 с.

7. Гамерська I.I. Контамінація як спосіб словотвору. Young Scientist. 2018, № 3.1 (55.1) March C. $28-30$. URL: http://molodyvcheny.in.ua/files/journal/2018/3.1/7.pdf.

8. Дубравська Д.М. Композити як одне з основних джерел розвитку і збагачення словникового складу англійської мови (на матеріалах британського національного Корпусу текстів (BNC). Лінгвістика ХХІ століття: нові дослідження і перспективи. Київ, 2012. С. 110-119.

9. Davy D. Shortening Phenomena in Modern English Word Formation: An Analysis of Clipping and Blending. Franco-British Studies. 2000. Vol. 29. P. 59-76.

10. Gries St.Th. Shouldn't it be breakfunch? A quantitative analysis of blend structure in English. Linguistics. Antwerp: Mouton de Groyter, 2004. Vol. 42. P. 639-667.

11. Kelly M.H. To «Brunch» or to «Brench»: Some Aspects of Blend Structure. Linguistics. 1998. Vol. 36. № 3. P. 579-590.

12. Benczes R. Creative Compounding in English. Amsterdam. Philadelphia: John Benjamins Publishing Company, 2006. 206 p.

13. Редько Є. Словотвірна контамінація в сучасних інноваційних процесах. $X X-X X I$ століття: жанрово-стильові й лінгвістичні метаморфози в украӥнській мові і літературі. Колективна монографія / за заг. ред. А. Архангельської. Olomouc : VUP, 2016. С. 205-229.

\section{REFRERENCES}

1. Tony Thorne. Language and Innovation. Coronaspeak. The Language of Covid-19 Goes Viral. Part 2. URL: https://language-and-innovation.com/2020/04/15/coronaspeak-part-2-the-language-of-covid-19-goes-viral/

2. New Words We Created Because of Coronavirus. URL: https://www.dictionary.com/e/s/new-words-wecreated-because-of-coronavirus/\#1

3. Erin Mccarty. $11 \mathrm{New}$ Words and Phrases Inspired by Coronavirus. URL: https://www.mentalfloss.com/ article/623726/new-words-inspired-coronavirus

4. Krasnytska K. Hlobalne yavysche Coronavirus yak nivyi kontsept $\mathrm{v}$ anhlomovniy lingvokulturniy kartyni svitu [Global phenomenon of Coronavitus in English-speaking lingual and cultural picture of the world]. Actual Issues of Humanities. Issue 32, vol. 1. 2020. P. 148-151. URL: http://journals.uran.ua/index. $\mathrm{php} / 2308-4855 /$ article/view/214491

5. Vabischevych N. Leksyko-semantychne pole 'vohnyu' $\mathrm{v}$ anhliyskiy movi. [Lexico-semantic field of 'Fire' in the English language]. URL: https://naub.oa.edu.ua/2012/leksyko-semantychne-pole-vohnyu-vanhlijskij-movi/

6. Linguistic Encyclopedic Dictionary by V.N. Yartseva. $2^{\text {nd }}$ edition. Moscow: Bolshaya Rossiyskaya Entsiklopediya publishers, 2002. 709 p. 
7. Hamerska I.I. Kontaminatsiya yak sposib slovotvoru [Contamination as a means of word-formation]. Young Scientist. Vol. 3.1 (55.1) March, 2018. C. 28-30. URL: http://molodyvcheny.in.ua/files/ journal/2018/3.1/7.pdf

8. Dubravska D.M. Kompozyty yak odne z osnovnyh dzherel rozvytku I zbahachennia slovnykovoho skladu anhliyskoyi movy [Compounds as one of the main sources of the development and enrichment of the vocabulary of the English language]. Linguistics of the $21^{\text {st }}$ century: new researches and prospects. Kyiv: Lohos Publishers, 2012. P. 110-119.

9. Davy D. Shortening Phenomena in Modern English Word Formation: An Analysis of Clipping and Blending. Franco-British Studies. 2000. Vol. 29. P. 59-76.

10. Gries St.Th. Shouldn't it be breakfunch? A quantitative analysis of blend structure in English. Linguistics. Antwerp: Mouton de Groyter, 2004. Vol. 42. P. 639-667.

11. Kelly M.H. To «Brunch» or to «Brench»: Some Aspects of Blend Structure. Linguistics. 1998. Vol. 36. № 3. P. 579-590.

12. Benczes R. Creative Compounding in English. Amsterdam / Philadelphia: John Benjamins Publishing Company, 2006. 206 p.

13. Redko Ye. Slovotvirna kontaminatsiya v suchasnyh innovatsiynyh protsesah [Word-forming contamination in modern innovational processes]. 20-21 century: genre, stylistic and linguistic metamorphoses in the Ukrainian language and literature. Collective monograph. Olomouc : VUP, 2016. P. 205-229. 